\title{
Chasing returns with high-beta stocks: Evidence from tax-privileged mutual funds in Thailand
}

\author{
Roongkiat Ratanabancheun • Kanis Saengchote*
}

Chulalongkorn Business School, Thailand

Received: 5 March 2020

Revised: 11 May 2020

Accepted:16 June 2020

\begin{abstract}
One proposed explanation for the low-beta anomaly - a puzzling finding that stocks with low systematic risk tend to earn higher returns than the CAPM predicts and vice versa - is that mutual funds drive up demand for high-beta stocks, leading to systematic mispricing. We find evidence that Thai equity mutual funds tend to alter their risk exposure in response to fund flows, but only for incentivized funds where investors receive immediate tax benefits. We argue that the benefits change the way investors make their decisions, raising an issue of how public policies may have unintended consequences in capital markets.
\end{abstract}

Keywords: high-beta stocks; mutual fund returns; low-beta anomaly; unintended consequence; public policy

JEL Classification Codes: G11, G23

\section{Introduction}

Numerous studies have documented how mutual fund investors tend to asymmetrically reward funds with stellar returns than penalize funds with poor returns (e.g. Chevalier and Ellison (1997), Huang et al. (2007), Sirri and Tufano (1998)). As fund managers tend to be rewarded by fund size, this convex flow-performance relationship can induce risk-shifting behavior where managers make risky investments to "chase returns" and attract inflows (e.g. Brown et al. (1996), Ha and Ko (2017)). In order to increase risk, mutual fund managers typically have few options, as usage of leverage, derivatives and short selling is restricted, and even if permitted, tend not to be employed. ${ }^{1}$ Because of this limitation, managers may resort to chasing returns by investing in riskier stocks instead.

\footnotetext{
*Corresponding author. E-mail: kanis@cbs.chula.ac.th.
}

Citation: Ratanabancheun, R., and Saengchote, K. (2021) Chasing returns with high-beta stocks: Evidence from tax-privileged mutual funds in Thailand, Economics and Business Letters, 10(1), 37-44.

DOI: $10.17811 / \mathrm{ebl} \cdot 10.1 .2021 .37-44$

${ }^{1}$ For example, in the U.S., section 18 of the Investment Company Act of 1940 restricts the ability of funds to issue "senior securities", which are defined as "any bond, debenture, note, or similar obligation or instrument constituting a security and evidencing indebtedness". In Thailand, the Securities and Exchange Commission restricts fund's leverage to $10 \%$ of total net assets. 
The demand for high-beta stocks from leverage-constrained and index-benchmarked investors such as mutual fund managers has been proposed by Baker et al. (2011) as candidate explanation for the low-beta anomaly, a puzzling empirical finding that stocks with low systematic risk tend to earn higher returns than the Capital Asset Pricing Model (CAPM) predicts - a phenomenon first documented by Black (1972) and continues to be the subject of investigation today. Recent studies by Boguth and Simutin (2018) and Christoffersen and Simutin (2017) show that U.S. mutual fund managers invest in riskier stocks to beat indices, and their increased risktaking is related to the returns of the betting-against-beta portfolio proposed by Frazzini and Pedersen (2014), shedding light on one potential source of the low-beta anomaly. ${ }^{2}$

In this article, we investigate the interplay between the low-risk anomaly and mutual fund management with an additional aspect of public policy. ${ }^{3}$ Thailand provides a unique setting for this research compared to other markets as the personal income tax code allows investors to deduct contributions made to qualifying funds against taxable income, giving investors immediate gains. This tax benefit can be substantial, which can affect how investors evaluate funds. This duality allows us to test the risk-flow sensitivity for the two classes of funds separately. To the best of our knowledge, only Thailand and India have this feature in their tax code. ${ }^{4} \mathrm{We}$ find that managers tend to adjust fund beta in response fund flows as conjectured, but only for tax-privileged funds. In addition to adding further insight to the low-beta anomaly, our article sheds new evidence on how public policies may have unintended consequences in capital markets. ${ }^{5}$

\section{Methods}

In Thailand, certain open-ended equity mutual funds are tax-privileged: individuals can deduct annual contributions from taxable income, as long as they keep their funds invested for specified periods of time. The policy was instigated in 2004 to encourage capital market participation and increase investment horizon and has proven to be very effective. By the end of December 2014, total net assets (TNA) of tax-privileged mutual funds grows to THB 500 billion, representing $51 \%$ of all equity funds' TNA.

There are two main classes of tax-privileged investments: the Long Term Equity Funds (LTFs), which are subjected to a 5-year lockup period (amended to 7 years for investments beginning 2016), and Retirement Mutual Funds (RMFs), which are subjected to a minimum of 5-year lockup period and cannot be redeemed until the investor's age reaches 55. As their names suggest, LTFs are intended to encourage indirect stock market participation, so all funds are required to hold at least $65 \%$ of total net assets in domestic equity, while RMFs are intended for retirement and thus have broader investment mandates. For example, there are RMFs that specialize in foreign equity, real estate investment trusts, fixed income instruments and even commodities. In our study, we select RMFs that invest in domestic equity which tend to have similar investment policies as their LTF counterparts. No tax-free redemption is allowed during the lockup period. If investments are sold prior to lockup expiry, investors must return the tax

\footnotetext{
${ }^{2}$ The betting-against-beta (BAB) portfolio by Frazzini and Pedersen (2014) involves taking a long position on low-beta stocks and short position on high-beta stocks in a way that has net zero investment and net zero average beta.

${ }^{3}$ Saengchote (2017) finds that the low-beta anomaly in Thailand is driven by high-beta stocks earning low returns rather than low-beta stocks earning high returns, which is consistent with the risk-increasing behavior proposed by Baker et al. (2011).

${ }^{4}$ In India, such funds are referred to as Equity Linked Saving Scheme (ELSS) which are subject to a lockup period of 3 years and qualify for tax benefit under Section 80C of the Income Tax Act 1961.

${ }^{5}$ Many untended effects of public policies can be found in health economics; for example, Badding et al. (2012), Gallet (2013), and Virabhak and Sohn (2009).
} 
benefits. In addition, they must pay capital gains tax on any profit, which is exempt for general mutual funds. In other words, they are set up to heavily discourage early redemption.

The investment limits are separate for LTFs and RMFs, and investors can contribute up to a maximum of $15 \%$ of taxable income or THB 500,000, whichever is greater. The cap is equivalent to taxable income of THB 3.3 million. The limits are very generous, as even top filers can earn substantial tax benefits. To put this into perspective, Thailand has progressive personal income tax rate ranging from 5\% to 35\% in 5\% increments. The income threshold for the $35 \%$ rate is THB 4 million, and the next bracket is THB 2 million to THB 4 million for the $30 \%$ rate. In principle, investors can make tax-deductible contributions of up to $30 \%$ of their taxable income annually. However, the RMF limit is combined with other retirement products, such as government pension fund contribution, provident fund contribution (an analogue to government pension fund sponsored by private companies on a voluntary basis) and retirement annuities.

LTFs are more popular in Thailand, as more than $86 \%$ of tax-privileged assets are held through LTFs, which have much shorter effective lockup period. The lockup periods are based on calendar dates, such that investment made in December of year t to January of year $t+1$ is counted as 2 years. For high-income individuals who minimize their lock-up period, the 35\% immediate benefit can augment a $6 \%$ per annum returns to more than $22 \% .{ }^{6}$ Investors tend to make their investments in the last quarter and sell in the first quarter to minimize the effective lockup period, as shown in Figure 1. This strategic behavior suggests that investors view tax deduction as the primary motive, which may affect their investment behavior. ${ }^{7}$

Figure 1. Calendar-Based Timing of Investment.

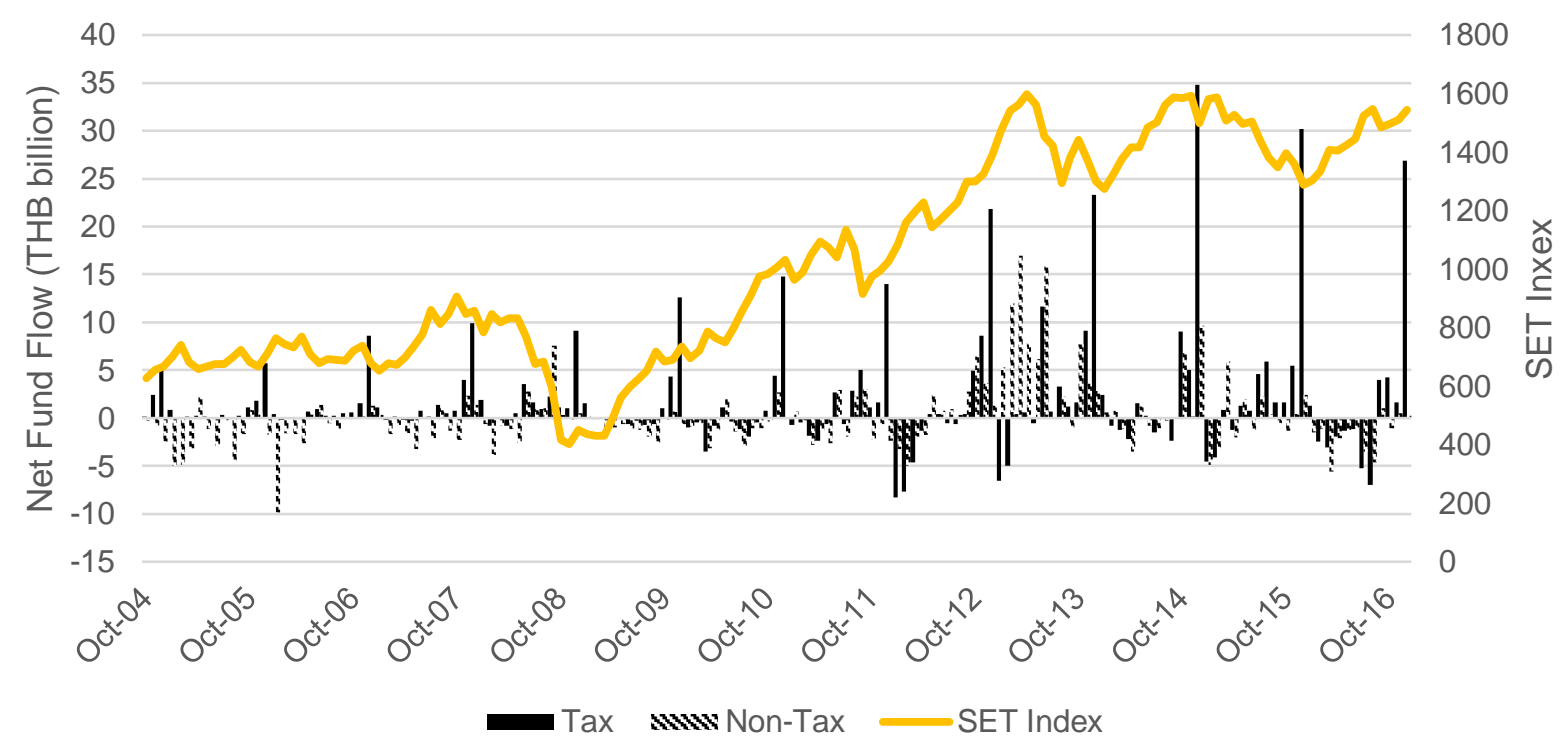

Note: This figure plots cumulative fund flows (computed as $\left.\left(\mathrm{TNA}_{\mathrm{i}, \mathrm{t}+1}-\mathrm{TNA}_{\mathrm{i}, \mathrm{t}}\left(1+\mathrm{r}_{\mathrm{i}, \mathrm{t}+1}\right)\right) / \mathrm{TNA}_{\mathrm{i}, \mathrm{t}}\right)$ in each month between October 2004 and December 2016 for privileged and non-privileged funds separately. SET Index is the value-weighted index of all stocks listed in the Stock Exchange of Thailand. Annual spikes for tax funds inflows occur regularly at December. The correlation coefficient between tax fund flows and SET Index is 0.11 and statistically insignificant, while the coefficient between non-tax fund flows and SET Index is 0.34 and statistically significant at $1 \%$ level, suggesting that non-tax flows are more market-driven, while tax flows are more strategic.

\footnotetext{
${ }^{6}$ If we incorporate the view that investor prefer immediate gratification, i.e. the present bias, the benefit is even larger. For a review of present bias, see O'Donoghue and Rabin (2015).

${ }^{7}$ We thank the anonymous referee for suggesting that the advantage can either increase or decrease investors' sensitivity to performance and helping us elaborate the argument.
} 
On the one hand, investors may be less concerned about performance as the gains are immediate from tax savings. In addition, tax-privileged funds in Thailand tend to be more advertised, which could lower the information cost as proposed by Huang et al. (2007) and reduce the performance sensitivity. If this is the case, the risk-flow relationship in tax-privileged funds is unlikely to be present. On the other hand, long lockup periods can be interpreted as greater transaction cost as proposed by Huang et al. (2007), which can increase performance sensitivity. Greater competition for fund flow as documented by Boguth and Simutin (2018), Christoffersen and Simutin (2017) and Ha and Ko (2017) also lead to the same prediction. In this case, we expect to see greater risk-flow relationship in tax-privileged funds.

To analyze the risk-flow relationship, we follow Sirri and Tufano (1998) and calculate annual fund flows as changes in assets adjusted for the returns scaled by lagged assets. We separate the analysis for tax-privileged and general funds (which we will refer to as "tax" and "non-tax" funds) and consider two versions: first with forward fund beta on fund flow (Equation 1), and second with future change in fund beta on fund flow (Equation 2). $X_{i t}$ is a vector of control variables that includes contemporaneous fund beta, log of fund size (TNA), and expense ratio.

$$
\text { Beta }_{i, t+1}=\sigma_{i}+\theta_{t}+\alpha \text { Flow }_{i t}+\mu^{\prime} X_{i t}+\eta R R e t_{i t}+\varepsilon_{i t}
$$

In Equation 2, $\Delta X_{i t}$ represents the first-differenced values of the variables used in Equation 1 , except fund flow and relative return. In this specification, we exclude the change in log TNA because it is highly correlated with fund flow given the way the flow variable is constructed (the correlation coefficient between the two variables is 0.81 and statistically significant at $1 \%$ level). The first-differenced specification is used to address potential endogeneity concerns associated with panel data. In addition, we include year $\left(\theta_{t}\right)$ and style $\left(\sigma_{i}\right)$ fixed effects in all regressions, and cluster standard errors by funds to account for serial correlation in the variables. Based on earlier discussion, our main coefficients of interest are $\alpha$ and $\gamma$.

$$
\Delta \text { Beta }_{i, t+1}=\sigma_{i}+\theta_{t}+\gamma \text { Flow }_{i t}+\phi^{\prime} \Delta X_{i t}+\eta R R e t_{i t}+\varepsilon_{i t}
$$

\section{Data}

We obtain fund type, returns, fees, TNA, fund holdings, and other characteristics from the Morningstar database from 2006 to 2016 . We focus on open-ended equity funds that have at least 5 years of data and TNA of at least THB 100 million (approximately USD 3 million). The equity holdings are used to compute the value-weighted, fund-level beta estimated from past returns from Datastream. ${ }^{8}$ Annual relative returns are computed as the differences between the funds' total returns and the benchmark index returns obtained from the Stock Exchange of Thailand. ${ }^{9}$ There are 161 funds, 65 of which are tax funds, with 1,420 fund-year observations. Summary statistics of key variables used in our analysis are reported in Table 1.

\section{Results}

Table 2 reports the regression result of Equation 1. The pooled result suggests that there is no relationship between fund flow and future fund risk, but further examination shows that the negative relationship (statistically significant at 5\% level) exists only for tax funds. In column

\footnotetext{
${ }^{8}$ We use the beta calculation method based on Frazzini and Pedersen (2014), where each stock's beta is calculated as the ratio of its covariance to the market return and the product of the stock's and market returns standard deviation.

${ }^{9}$ More than $80 \%$ of the funds are benchmarked to the SET Index, which is the market-value weighted index of all listed stocks in the Stock Exchange of Thailand. The second most popular benchmark is the SET50 Index, which includes 50 stocks with the largest market capitalization.
} 
Table 1. Summary statistics.

\begin{tabular}{lrrrrr}
\hline Tax funds & & & & & \\
Variable & Mean & Std Dev & $\boldsymbol{P 1 0}$ & $\boldsymbol{P 5 0}$ & $\boldsymbol{P 9 0}$ \\
\hline Fund beta $t+1$ & 0.94 & 0.23 & 0.67 & 0.93 & 1.24 \\
Fund flow $t$ (in decimals) & 0.33 & 0.81 & -0.10 & 0.13 & 0.73 \\
Fund size $t$ (in THB millions) & 2,809 & 5,532 & 87 & 819 & 6,740 \\
Expense ratio $t$ (in \%) & 1.81 & 0.48 & 1.14 & 1.86 & 2.27 \\
Relative return t (in decimals) & 0.05 & 0.07 & -0.04 & 0.04 & 0.14 \\
\hline Observations & 572 & & & & \\
Number of funds & 65 & & & & \\
\hline \hline Non-Tax funds & & & & & \\
Variable & Mean & Std Dev & $\boldsymbol{P 1 0}$ & $\boldsymbol{P 5 0}$ & $\boldsymbol{P 9 0}$ \\
\hline Fund beta $t+1$ & 0.97 & 0.21 & 0.76 & 0.95 & 1.24 \\
Fund flow $t$ (in decimals) & 0.03 & 0.68 & -0.35 & -0.10 & 0.36 \\
Fund size $t$ (in THB millions) & 910 & 1,680 & 77 & 305 & 2,413 \\
Expense ratio $t$ (in \%) & 1.65 & 0.48 & 0.94 & 1.80 & 2.22 \\
Relative return $t$ (in decimals) & 0.06 & 0.06 & -0.01 & 0.05 & 0.14 \\
\hline Observations & 848 & & & & \\
Number of funds & 96 & & & & \\
\hline \hline
\end{tabular}

Note: This table reports the average, standard deviation, and the key percentiles of fund characteristics. $t$ or $t+1$ denote the year (ending in September) in which the characteristics are measured. Fund beta is calculated as the value-weighted average betas based on the stock holdings reported as of (or latest available prior to) September in each year. Stock betas are estimated following Frazzini and Pedersen (2014), where each stock's beta is calculated as the ratio of its covariance to the market return and the product of the stock's and market returns standard deviation. Relative return is computed relative to the relevant benchmark (mostly SET Index and SET50 Index) in each year. Fund flow at $t+1$ is computed as $\left(\mathrm{TNA}_{\mathrm{i}, \mathrm{t}+1}-\mathrm{TNA}_{\mathrm{i}, \mathrm{t}}\left(1+\mathrm{r}_{\mathrm{i}, \mathrm{t}+1}\right)\right) / \mathrm{TNA}_{\mathrm{i}, \mathrm{t}}$. Fund size (total net assets) and fund expenses are retrieved from Morningstar. Tax funds are mutual funds which are tax-privileged.

4 and 5, we further partition our sample into LTFs and RMFs and find that the negative relationship is driven by LTFs. As LTFs and RMFs in our sample have similar investment policies (at least 65\% of TNA in domestic equity), this difference is likely due lower popularity of RMFs for equity investment, so the incentive for fund managers to chare returns is higher for LTFs. ${ }^{10}$ Equation 2 is more stringent: a negative $\gamma$ means funds that experience lower flows will change beta in the next period. By first differencing and including fixed effects, this specification absorbs many unobserved effects, as evidenced by higher adjusted R-squared values. The result reported in Table 3 is similar: only tax funds (LTFs) exhibit this negative flow-risk relationship, with greater statistical significance (1\% level) and magnitude. To put the numbers into perspective, a one standard deviation decline in fund flow is associated with a 0.044 unit increase in fund beta.

Our finding corroborates the view of Boguth and Simutin (2018) and Christoffersen and Simutin (2017) that competition for fund flows from investors who make decisions based on relative returns can affect fund managers' risk-taking strategy. For many, the benefits are large: Muthitacharoen (2017) estimates that 36\% of fund-related deductions are made by filers who face 30-35\% marginal tax rates, which translates into significant annualized returns. While the result can also be viewed as support for higher transaction cost effect proposed by Huang et al.

\footnotetext{
${ }^{10}$ Using Thai tax filings data, Muthitacharoen (2017) estimates that total LTF contribution is 2.65 times greater than RMF contribution. Given that $86 \%$ of tax-privileged equity TNA is LTFs, the majority of RMF contribution must be in other asset classes, most likely fixed income instruments. Certain equity RMFs are eligible as provident fund transfer destination, so it is possible that RMF flows are partly driven by employees leaving their jobs and switching out of their employee-sponsored funds into these RMFs.
} 
Table 2. Fund Flow and Mutual Fund Risk-Taking.

\begin{tabular}{|c|c|c|c|c|c|}
\hline Depvar: Fund beta $(t+1)$ & $\begin{array}{r}(1) \\
\text { Pooled } \\
\end{array}$ & $\begin{array}{r}(2) \\
\text { Tax }\end{array}$ & $\begin{array}{r}(3) \\
\text { Non-Tax } \\
\end{array}$ & $\begin{array}{r}(4) \\
\text { LTFs }\end{array}$ & $\begin{array}{r}(5) \\
\text { RMFs }\end{array}$ \\
\hline Fund flow & $\begin{array}{r}-0.0098 \\
(0.0079)\end{array}$ & $\begin{array}{r}-0.0260 * * \\
(0.0104)\end{array}$ & $\begin{array}{r}0.0078 \\
(0.0123)\end{array}$ & $\begin{array}{r}-0.0286 * * \\
(0.0116)\end{array}$ & $\begin{array}{r}-0.0077 \\
(0.0142)\end{array}$ \\
\hline Fund beta & $\begin{array}{r}0.2737 * * * \\
(0.0395)\end{array}$ & $\begin{array}{r}0.2921 * * * \\
(0.0506)\end{array}$ & $\begin{array}{r}0.2139 * * * \\
(0.0724)\end{array}$ & $\begin{array}{r}0.2901 * * \\
(0.1388)\end{array}$ & $\begin{array}{r}0.3673 \\
(0.2556)\end{array}$ \\
\hline Log fund size & $\begin{array}{l}-0.0066^{*} \\
(0.0038)\end{array}$ & $\begin{array}{r}-0.0117 * * \\
(0.0055)\end{array}$ & $\begin{array}{r}-0.0046 \\
(0.0054)\end{array}$ & $\begin{array}{r}-0.0155 * * \\
(0.0066)\end{array}$ & $\begin{array}{r}-0.0014 \\
(0.0132)\end{array}$ \\
\hline Expenses & $\begin{array}{r}-0.0197 * * \\
(0.0100)\end{array}$ & $\begin{array}{r}-0.0256 \\
(0.0168)\end{array}$ & $\begin{array}{r}-0.0143 \\
(0.0128)\end{array}$ & $\begin{array}{r}-0.0177 \\
(0.0194)\end{array}$ & $\begin{array}{r}-0.0703 * * \\
(0.0311)\end{array}$ \\
\hline Relative return & $\begin{array}{r}0.2073 * * \\
(0.0944)\end{array}$ & $\begin{array}{r}0.3403 * * * \\
(0.1252)\end{array}$ & $\begin{array}{r}-0.0034 \\
(0.1384)\end{array}$ & $\begin{array}{r}0.3038 * * * \\
(0.0608)\end{array}$ & $\begin{array}{r}0.0936 \\
(0.0959)\end{array}$ \\
\hline Observations & 1,420 & 572 & 848 & 415 & 157 \\
\hline Adjusted R-squared & 0.512 & 0.499 & 0.532 & 0.467 & 0.620 \\
\hline
\end{tabular}

Note: This table report results from regressions of fund beta in year $t+1$ on fund flow in year $t$ and fund characteristics measured at the end of year $t$ (ending in September), as specified in Equation 2. Fund beta is calculated as the value-weighted average betas based on the stock holdings reported as of (or latest available prior to) September in each year. Stock betas are estimated following Frazzini and Pedersen (2014), where each stock's beta is calculated as the ratio of its covariance to the market return and the product of the stock's and market returns standard deviation. All regressions include year and style fixed effects. Fund beta in year $t$ is included to account for potential serial correlation of beta. Standard errors, reported in parenthesis, are clustered by fund. Stars correspond to statistical significance level, with *** and *** representing 10 percent, 5 percent and 1 percent level respectively. See Table 1 for definition of other variables.

Table 3. Fund Flow and Change in Mutual Fund Risk-Taking.

\begin{tabular}{lrrrrr}
\hline \hline $\begin{array}{l}\text { Depvar: Change in Fund } \\
\text { beta }(\mathbf{t}, \mathbf{t + 1})\end{array}$ & $\begin{array}{r}(\mathbf{1}) \\
\text { Pooled }\end{array}$ & $\begin{array}{r}\mathbf{( 2 )} \\
\text { Tax }\end{array}$ & $\begin{array}{r}\mathbf{( 3 )} \\
\text { Non-Tax }\end{array}$ & $\begin{array}{r}\mathbf{( 4 )} \\
\text { LTFs }\end{array}$ & $\begin{array}{r}\mathbf{( 5 )} \\
\text { RMFs }\end{array}$ \\
\hline Fund flow $(t)$ & -0.0061 & $-0.0579 * * *$ & 0.0148 & $-0.0541 * * *$ & -0.1068 \\
& $(0.0149)$ & $(0.0159)$ & $(0.0176)$ & $(0.0159)$ & $(0.0812)$ \\
Change in Fund beta $(t-1$, & $-0.5512^{* * *}$ & $-0.5180^{* * *}$ & $-0.5738^{* * *}$ & $-0.5323 * * *$ & $-0.4537 * * *$ \\
$t)$ & & & & & \\
& $(0.0192)$ & $(0.0308)$ & $(0.0268)$ & $(0.0319)$ & $(0.0941)$ \\
Change in Expenses $(t-1, t)$ & -0.0177 & 0.0123 & -0.0506 & 0.0077 & $0.1094 *$ \\
& $(0.0267)$ & $(0.0457)$ & $(0.0350)$ & $(0.0538)$ & $(0.0606)$ \\
Relative return $(t)$ & 0.0621 & 0.0778 & 0.0757 & 0.0298 & 0.2664 \\
& $(0.1021)$ & $(0.1627)$ & $(0.1251)$ & $(0.1847)$ & $(0.3423)$ \\
\hline & & & & & \\
Observations & 1,269 & 519 & 750 & 376 & 143 \\
Adjusted R-squared & 0.725 & 0.693 & 0.752 & 0.669 & 0.747 \\
\hline \hline
\end{tabular}

Note: This table report results from regressions of change in fund beta from year $t$ to year $t+1$ on fund flow in year $t$ and changes in fund characteristics measured at the end of year $t$ (ending in September), as specified in Equation 3. Fund beta is calculated as the value-weighted average of betas based on the stock holdings reported as of (or latest available prior to) September in each year. Stock betas are estimated following Frazzini and Pedersen (2014), where each stock's beta is calculated as the ratio of its covariance to the market return and the product of the stock's and market returns standard deviation. All regressions include year and style fixed effects. Standard errors, reported in parenthesis, are clustered by fund. Stars correspond to statistical significance level, with *, ** and *** representing 10 percent, 5 percent and 1 percent level respectively. See Table 1 for definition of other variables. 
(2007), it is important to note that net inflows of tax-deductible investment are positive in every year and uncorrelated with market performance (unlike non-tax funds), as evident in Figure 1. This continuity makes fund managers more likely to compete for such flows. In unreported regressions, we confirm that the convex flow-performance sensitivity documented by Sirri and Tufano (1998) exists in Thailand and is stronger for tax funds. Taken together, we interpret our finding as evidence of returns chasing behavior through risk-shifting as a competitive response to investors' performance sensitivity.

The tendency for fund managers to buy high beta stocks can explain the finding of Saengchote (2017) that the low-beta anomaly in Thailand is more about high-beta stocks earning low returns than low-beta stocks earning high returns. As mutual funds cannot short stocks, their long positions can lead to overpriced stocks that cannot be arbitraged away, similar to the findings of Stambaugh et al. $(2012,2015)$. The finding suggests that short selling against mutual funds can be profitable, as documented by Arif et al. (2015).

\section{Concluding remarks}

Capital market frictions can artificially affect demand for assets and compel investors to make decisions that are inconsistent with traditional asset pricing models. In this article, we contribute to the growing evidence that frictions in mutual fund management and the beta anomaly are intertwined, and, more importantly, provide new evidence of how well-intentioned public policies may inadvertently create market frictions.

\section{Acknowledgments}

We thank Francisco J. Delgado (editor), two anonymous referees and participants of the 2018 SEC Working Paper Forum for their helpful comments. This research received support from Chulalongkorn Business School.

\section{References}

Arif, S., Ben-Rephael, A., and Lee, C. (2015) Do short-sellers profit from mutual funds? evidence from daily trades, Rock Center for Corporate Governance at Stanford University Working Paper, 195.

Badding, K. D., Stephenson, E. F., and Yeoh, M. M. (2012) Health-care reform and bankruptcy: evidence from Massachusetts, Applied Economics Letters, 19(17), 1741-1744.

Baker, M., Bradley, B., and Wurgler, J. (2011) Benchmarks as limits to arbitrage: Understanding the low-volatility anomaly, Financial Analysts Journal, 67(1), 40-54.

Black, F. (1972) Capital market equilibrium with restricted borrowing, The Journal of Business, 45(3), 444-455.

Boguth, O., and Simutin, M. (2018) Leverage constraints and asset prices: Insights from mutual fund risk taking, Journal of Financial Economics, 127(2), 325-341.

Brown, K. C., Harlow, W. V., and Starks, L. T. (1996) Of tournaments and temptations: An analysis of managerial incentives in the mutual fund industry, The Journal of Finance, 51(1), 85-110.

Chevalier, J., and Ellison, G. (1997) Risk taking by mutual funds as a response to incentives, Journal of Political Economy, 105(6), 1167-1200.

Christoffersen, S. E., and Simutin, M. (2017) On the demand for high-beta stocks: Evidence from mutual funds, The Review of Financial Studies, 30(8), 2596-2620.

Frazzini, A., and Pedersen, L. H. (2014) Betting against beta. Journal of Financial Economics, 111(1), 1-25. 
Gallet, C. A. (2013) Tobacco control and obesity: evidence from a cross section of countries, Applied Economics Letters, 20(1), 80-83.

Ha, Y., and Ko, K. (2017) Why do fund managers increase risk?, Journal of Banking \& Finance, 78, 108-116.

Huang, J., Wei, K. D., and Yan, H. (2007) Participation costs and the sensitivity of fund flows to past performance, The Journal of Finance, 62(3), 1273-1311.

Muthitacharoen, A. (2017) Five new perspectives from Thai tax returns, PIER aBRIDGEd, 19.

O'Donoghue, T., and Rabin, M. (2015) Present bias: Lessons learned and to be learned, American Economic Review, 105(5), 273-79.

Sirri, E. R., and Tufano, P. (1998) Costly search and mutual fund flows, The Journal of Finance, 53(5), 1589-1622.

Stambaugh, R. F., Yu, J., and Yuan, Y. (2012) The short of it: Investor sentiment and anomalies, Journal of Financial Economics, 104(2), 288-302.

Stambaugh, R. F., Yu, J., and Yuan, Y. (2015) Arbitrage asymmetry and the idiosyncratic volatility puzzle, The Journal of Finance, 70(5), 1903-1948.

Virabhak, S., and Sohn, W. (2009). The impact of Medicaid's preferred drug lists on physicians' prescribing behaviour, Applied Economics, 41(21), 2705-2725. 